\title{
Use of coffee by-products for the cultivation of Pleurotus citrinopileatus and Pleurotus salmoneo-stramineus and its impact on biological properties of extracts thereof
}

\author{
Ana C. Freitas, \\ Mariana B. Antunes, \\ Dina Rodrigues, \\ Sérgio Sousa, \\ Manuela Amorim, \\ Maria F. Barroso, \\ Ana Carvalho, \\ Sandra M. Ferrador, \\ Ana M. Gomes
}

\begin{abstract}
ncorporating spent coffee grounds (SCGs), a by-product from coffee brewing, in growth substrate of beneficial edible mushrooms is an approach that has to be further studied due to its potential positive outcomes: environmental impact mitigation, production costs reduction and beneficial impact on consumer health. Hence, cultivation of Pleurotus citrinopileatus and Pleurotus salmoneo-stramineus was tested using SCG which enabled maximum production yield of $P$. citrinopileatus which was of $25.1 \%(\mathrm{w} / \mathrm{w})$. Variable antidiabetic potential was observed between aqueous and enzymatic extracts (3.8\%-29\% inhibition) regardless species and substrates, whereas aqueous extract of $P$. citrinopileatus grown in substrate without SCG stood out presenting the highest antioxidant activity and inhibition activity of angiotensin I-converting enzyme $\left(\mathrm{IC}_{50}=123 \mu \mathrm{g} \mathrm{mL} \mathrm{L}^{-1}\right)$. Ethanolic and aqueous extracts of both Pleurotus species grown in the presence or absence of SGC proved to be an interesting prebiotic source for growth of Bifidobacterium animalis Bo in comparison with fructooligosaccharides (FOS).
\end{abstract}

\section{Keywords}

Antioxidant and prebiotic, caffeine, extraction, mushrooms, Pleurotus spp., spent coffee grounds, yield.

\section{Introduction}

Mushrooms are not only added-value foods because of their sensorial and nutritional characteristics but also due to their biological properties (Carrasco-González et al., 2017). They are a good source of protein, fibre, vitamins and minerals and of bioactive compounds such as phenolic compounds, polysaccharides, terpenes and steroids (Moon \& Lo, 2013), which have been used as a medicinal or nutraceutical application (Sabaratnam et al., 2011).

Solid-state fermentation as bioconversion processes where food protein is recovered from lignocellulosic materials has been used successfully for the cultivation of mushrooms (Philippoussis, 2009) namely several species of Pleurotus genus such as P. ostreatus, P. sajor caju or P. eryngii. Other less explored species such as P. citrinopileatus (golden oyster) and P. salmoneo-stramineus (pink oyster) also have tremendous commercial and biological potential and were selected as target species in this study. Saprophyte mushrooms as Pleurotus spp. are known to be easily cultivable in a diversity of organic substrates including different cereal straws or other agricultural by-products (Petre et al., 2016). Coffee by-products, in particular, spent coffee grounds (SCGs) which consist of residues of used coffee grounds resulting from soluble coffee production, have also begun to be tested as an important alternative. This by-product is important because almost $50 \%$ of the world coffee production is processed for soluble coffee (Ramalakshmi et al., 2009; Esquivel \& Jiménez, 2012) resulting in over ten million tons of solid residues generated yearly from coffee agro-industry worldwide (Echeverria \& Nuti, 2017). 
Spent coffee grounds possess high content of water (80\%-85\%), organic load with $8.6 \%$ cellulose, $36.7 \%$ hemicellulose and $13.6 \%$ of protein being an acidic residue (Mussato et al., 2011a).

Added-value uses of SCGs are environmentally sound and fundamental for circular economy; disposal or utilisation of SCG has included sewer discharge, sanitary land fill, incineration or cattle feed (Ramalakshmi et al., 2009). However, the chemical composition of SCGs makes this by-product a substrate of high biotechnological value able to be used as a substrate for cultivation (Mussato et al., 2011a). Some studies have been published on culturing of Pleurotus spp. using this agro-industrial by-product (Martínez-Carrera et al., 1985; Thielke, 1989; Velázquez-Cedeño et al., 2002; Mata et al., 2005; Salmones et al., 2005). Moreover, research is warranted to perceive its impact on growth and bioactives composition of different Pleurotus spp. which composition is easily affected by the growth substrate and conditions. Furthermore, to test for such bioactivity, extracts are normally prepared. Water-based extraction is not only food compatible, nonexpensive and environment-friendly but also could have lower selectivity and extraction efficiency (Herrero et al., 2006). Enzyme-assisted extraction (EAE) has potential because hydrolytic action enzymes on natural-derived products could weaken or disrupt cell wall structure as well as breakdown complex interior storage compounds releasing compounds such as polysaccharides, peptides or amino acids (Wang et al., 2010). Based on the above rationale, this study endeavoured to pursue several objectives: (i) to cultivate P. citrinopileatus and P. salmoneo-stramineus, testing the effect of incorporating SCG in commercial organic substrate; (ii) to evaluate the impact of different extraction modes on the yield and biological potential of the extracts. To our best knowledge, this is the first fourfactor study combining the effects of species-substrate-extraction-bioactivity, where different extraction modes are applied to the selected Pleurotus species grown on different substrates reporting their consequent biological potential (antioxidant, antidiabetic, antihypertensive and prebiotic activities).

Material and methods

Strains and culture conditions

Strains of Pleurotus citrinopileatus (synonym of Pleurotus cornucopiae var. citrinopileatus; M2502) and Pleurotus salmoneo-stramineus (synonym of P. ostreatoroseus or P. djamor; PD2708) were obtained from Mycelia (Nevele, Belgium).

Cultivation was performed using sterile filter bags with two different sterilised organic substrates. Substrate I, consisted in $38 \%(\mathrm{w} / \mathrm{w})$ sawdust, $5 \%(\mathrm{w} / \mathrm{w})$ wood shavings, $20 \%(\mathrm{w} / \mathrm{w})$ wood straw, $18 \%(\mathrm{w} / \mathrm{w})$ crushed grain corn, 13\%(w/w) wheat bran, $6 \%(\mathrm{w} / \mathrm{w}) \mathrm{crushed}$ oil seed cake with $68 \%(\mathrm{w} / \mathrm{w})$ water content, was obtained from Mycelia. Substrate II consisted on $50 \%(\mathrm{w} / \mathrm{w})$ of substrate I and $50 \%(\mathrm{w} / \mathrm{w})$ sterilised cold SCG. Spent coffee grounds were obtained from local coffee shop and sterilised at $121^{\circ} \mathrm{C}$ through 120 min. Once cooled, it was mixed, under aseptic conditions, with sterilised substrate I. Filter bags containing $3.5 \mathrm{Kg}$ of substrate were inoculated with $10 \%(\mathrm{w} / \mathrm{w})$ spawn from one of the two precultured Pleurotus strains. Four replicates were used for each production making a total of sixteen bags. Inoculated bags were incubated in darkness at $22-24{ }^{\circ} \mathrm{C}$ until mycelia had completely covered the substrate and appearance of primordia which took 20-24 days for substrate I and 25-30 days for substrate II. Mushroom fructification occurred after 5-10 days at $18-20^{\circ} \mathrm{C}$ under photoperiods of $12 \mathrm{~h}$ depending of the substrate and cultured Pleurotus strain. After fructification and mushroom growth to an average size of $5 \mathrm{~cm}$, entire clean mushrooms from each producing bag were cut off and dried in a ventilated drier over $24 \mathrm{~h}$ between 40 and $60^{\circ} \mathrm{C}$ and subsequently milled to less than $1.0 \mathrm{~mm}$ using a grinder. Production yield, resulting from the mixture of three fructifications, was obtained by determining the ratio of mushroom wet weight in comparison with original substrate wet weight. The content of caffeine in the organic substrates and in the mushrooms was determined according to ISO $20481: 2008$.

Proximate composition of mushrooms and extraction

Moisture and organic matter were determined according to AOAC methods (1990). Protein content was determined by the Kjeldahl method adapted from US ISO 5983-1 using 4.38 as converting factor to protein (Kulshreshtha et al., 2013). Total fat was determined by gravimetric Soxhlet method using petroleum ether for extraction, whereas total sugar content was determined indirectly by subtracting protein and fat content from total organic content. 
Seven replicated hot water extraction (HWE) and enzymatic-assisted extraction (EAE) with Alcalase (Sigma-Aldrich, USA) an extracellular alkaline protease (Subtilisin, EC 3.4.21.62) were performed according to Rodrigues et al. (2017).

Three replicated ethanolic extractions (EtOH_Ext) were performed with $5 \mathrm{~g}$ of dried and milled mushroom dispersed in $45 \mathrm{~mL}$ of ethanol $\left(70 \% \mathrm{v} / \mathrm{v}\right.$; Panreac, Spain) and incubated in an agitated water bath at $25^{\circ} \mathrm{C}$ for $14 \mathrm{~h}$. The ethanolic solution was then centrifuged at 5000 $\mathrm{g}$ for $10 \mathrm{~min}$ at $4{ }^{\circ} \mathrm{C}$ (centrifuge Medifriger BL-S; JP Selecta, Spain), and the supernatant brought almost to dryness with a rotary evaporator (Büchi, R-210, Switzerland). The residue was redissolved in $5.0 \mathrm{~mL}$ deionised water, and the extract frozen at $-80{ }^{\circ} \mathrm{C}$ until lyophilisation.

All extracts were frozen $\left(-80^{\circ} \mathrm{C}\right)$ and lyophilised and then weighed and stored in desiccators in the dark, at room temperature until further analysis. The extraction yield was calculated based on the ratio of weight of lyophilised extract to the weight of extracted dried mushroom. Content of total sugars in the different extracts was determined by the phenol-H2SO4 method (Dubois et al., 1956) using glucose $(0-200 \mu \mathrm{g} \mathrm{mL}-1)$ as a standard.

Evaluation of biological properties of the extracts

Antidiabetic activity

The $\alpha$-glucosidase inhibitory activity was determined in 96-well plates according to the method described in Rodrigues et al. (2017), and antidiabetic activity was expressed as percentage inhibition of $\alpha$-glucosidase.

Antioxidant activity

Total phenolic content (TPC) in all different extracts was determined according to Mendes et al. (2016). For antioxidant capacity assays, ferric reduction activity power (FRAP) was determined according to Paz et al. (2015), whereas scavenging of radical ABTS•+ (ABTS) and oxygen radical absorption capacity (ORAC) assays were in turn performed according to Mendes et al. (2016). All assays were performed in triplicate, and quantifications were based on calibration curves using gallic acid for TPC, ascorbic acid for FRAP and ABTS as well as Trolox for ORAC, respectively.

Antihypertensive activity

All extracts were evaluated by the angiotensin I-converting enzyme (ACE) assay according to Tavares et al. (2011). Inhibition activity of

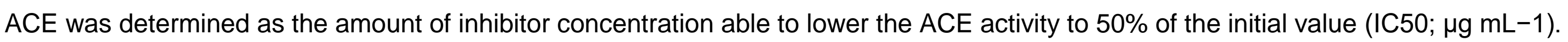

Prebiotic activity and sugars and organic acid analysis

Potential prebiotic activity of mushroom extracts was evaluated in vitro by measuring their impact on the growth of two different probiotic strains, namely Lactobacillus acidophilus Ki (DSM, Australia) and Bifidobacterium animalis Bo (CSK, Netherlands). Prebiotic activity was assessed in triplicate by enumeration of viable cell numbers of probiotic strains grown in MRS broth without glucose but supplemented with each of the extracts (2\%) throughout $48 \mathrm{~h}$. At each sampling point $(0,4,6,8,10,12,24$ and $48 \mathrm{~h})$, inoculated MRS broth was plated, in duplicate, on MRS agar and the viable cells were enumerated according to procedures described in Rodrigues et al. (2015). Strains growth in MRS broth with $2 \%$ of glucose or $2 \%$ of fructooligosaccharides (FOS, Orafti®P95) (positive controls) as well as without glucose (negative control) was included. The selection of the two probiotic strains and of the extracts (ethanolic and hot water extracts) was based on previous growth curves obtained by absorbance measurements at $660 \mathrm{~nm}$ (data not shown). For each probiotic strain grown in different carbon sources, specific growth rates $(h-1)$ were calculated.

The analysis of sugars and organic acids by HPLC was done according to Rodrigues et al. (2011) in samples of $500 \mu \mathrm{L}$ collected from each batch culture at different sampling points $(0,6,12,24$ and $48 \mathrm{~h})$. 
Data are presented as average plus standard deviation. One-way analysis of variance was carried out using SPSS (v 23.0, SPSS Chicago, IL, USA) associated to Tukey test to assess the different significant sources of variation $(P=0.05)$.

Results and discussion

Fructification and proximate composition of cultivated mushrooms

Production yield and proximate composition of P. citrinopileatus and of P. salmoneo-stramineus mushrooms are displayed in Table 1. No negative effect from the incorporation of SGC in organic substrate was observed for the production of $P$. citrinopileatus both at yield level and mushroom composition. The maximum expected yield, which according to substrate supplier Mycelia would be of $25 \%(\mathrm{w} / \mathrm{w})$, was observed in both substrates including substrate II which incorporated 50\%(w/w) sterilised SCG. No statistical differences were observed in terms of organic content and total protein for $\mathrm{P}$. citrinopileatus grown in both organic substrates which were similar to those published by Rodrigues et al. (2015). Significant differences were observed for total fat, total sugar and content of caffeine. Pleurotus citrinopileatus grown in substrate II, incorporating SCG, had slightly higher content in total fat, less total sugar content and had 0.08 $\mathrm{g} / 100 \mathrm{gdry}$ mushroom of caffeine. Higher values of total fat ( $3.5 \mathrm{~g} / 100 \mathrm{gdry}$ mushroom) but lower total sugar content $(54.7 \% \mathrm{~g} / 100 \mathrm{gdry}$ mushroom) were reported by Rodrigues et al. (2015) for P. citrinopileatus. According to our knowledge, no reports with cultivation of $P$. citrinopileatus using SCG were found in the literature. However, according to Salmones et al. (2005), four of the Pleurotus spp. studied (P. ostreatus, P. pulmonarius and P. djamor) were able to increase their productivities when cultured in sterilised coffee pulp. No significant differences in terms of biological efficiency among strains of $P$. ostreatus and P. pulmonarius cultivated in pasteurised coffee pulp were also reported by Velázquez-Cedeño et al. (2002).

\begin{tabular}{|c|c|c|c|c|c|c|c|c|c|c|c|c|}
\hline Mushroom & $\begin{array}{l}\text { Organic } \\
\text { substrate }\end{array}$ & $\begin{array}{l}\text { Yield } \\
\left(g_{\text {muahtroor }}\right. \\
100 \text { gsubst }\end{array}$ & & $\begin{array}{l}\text { Tota } \\
\text { (g/1 } \\
g_{\text {mua }}\end{array}$ & $\begin{array}{l}\text { al solids } \\
00 \\
\text { throom) }\end{array}$ & $\begin{array}{l}\text { Organi } \\
\text { lg/100 } \\
\text { gdry mu }\end{array}$ & ic matter & $\begin{array}{l}\text { Total Protei } \\
\text { (g/100 } \\
\text { 9dry muahroom }\end{array}$ & $\begin{array}{ll}\text { ein } & \text { Total Fat } \\
& \text { ( } g / 100 \\
& \text { gatry mushroor }\end{array}$ & $\begin{array}{ll} & \text { Total } \\
& \text { Sugar }{ }^{1} \\
& \text { (g/100 } \\
\text { adry muat }\end{array}$ & $\begin{aligned} & \text { Caffe } \\
& (\mathrm{g} / 10 \\
& g_{\mathrm{dry}}\end{aligned}$ & $\begin{array}{l}\text { eine } \\
00 \\
\text { mushroom) }\end{array}$ \\
\hline \multirow[t]{2}{*}{ P. citrinopileatus } & Substrate I & \multicolumn{2}{|c|}{$25.1 \pm 0.5^{*}$} & \multicolumn{2}{|c|}{$9.7 \pm 0.1^{\prime \prime}$} & \multicolumn{2}{|c|}{$93.4 \pm 0.1^{\circ}$} & $23.5 \pm 1.1^{\prime \prime}$ & $2.0 \pm 0.0^{a}$ & 67.9 & \multicolumn{2}{|c|}{$\angle \mathrm{LOD}^{2}$} \\
\hline & Substrate II & \multirow{3}{*}{\multicolumn{2}{|c|}{$\begin{aligned} 25.0 & \pm 0.3^{5} \\
3.7 & \pm 0.2^{b}\end{aligned}$}} & \multicolumn{2}{|c|}{$9.6 \pm 0.1^{\circ}$} & \multicolumn{2}{|c|}{$92.5 \pm 0.2^{2}$} & $24.1 \pm 1.6^{\mathrm{a}}$ & $2.5 \pm 0.3^{b}$ & 65.9 & \multicolumn{2}{|c|}{$0.08 \pm 0.01$} \\
\hline \multirow{2}{*}{$\begin{array}{l}\text { P. salmoneo- } \\
\text { stramineus }\end{array}$} & Substrate I & & & \multicolumn{2}{|c|}{$17.7 \pm 0.1^{b}$} & \multicolumn{2}{|c|}{$90.5 \pm 0.1^{b}$} & & $2.1 \pm 0.6^{a}$ & $\begin{array}{l}65.9 \\
55.6\end{array}$ & \multicolumn{2}{|c|}{$\mathrm{LOD}^{2}$} \\
\hline & Substrate II & & & \multicolumn{2}{|c|}{$17.4 \pm 0.2^{b}$} & \multicolumn{2}{|c|}{$\begin{array}{l}90.5 \pm 0.1^{15} \\
91.5 \pm 0.1^{\text {ab }}\end{array}$} & $\begin{array}{l}32.8 \pm 0.4^{-} \\
27.4 \pm 0.5^{\text {ab }}\end{array}$ & $2.1 \pm 0.4^{a}$ & 62.1 & \multicolumn{2}{|c|}{$0.06 \pm 0.01$} \\
\hline \multirow[b]{2}{*}{ Mushroom } & \multirow[b]{2}{*}{$\begin{array}{l}\text { Organic } \\
\text { substrate }\end{array}$} & \multicolumn{5}{|c|}{ Aqueous extracts (HWE) } & \multicolumn{3}{|c|}{ Enzymatic extracts (EA_Alcalase) } & \multicolumn{3}{|c|}{$\begin{array}{l}\text { Ethanolie } \\
\text { extracts (EtOH_Ext) }\end{array}$} \\
\hline & & Yield $^{3}$ & $\begin{array}{l}\text { Tota } \\
\text { suga } \\
\text { cont }\end{array}$ & ar & $\begin{array}{l}\alpha \text {-Glueos } \\
\text { inhibitio }\end{array}$ & $\begin{array}{l}\text { ssidase } \\
\text { on (\%) }\end{array}$ & Yield & $\begin{array}{l}\text { Total } \\
\text { sugar } \\
\text { content }\end{array}$ & $\begin{array}{l}\alpha \text {-Glucosidase } \\
\text { inhibition }(\%)\end{array}$ & Yield & $\begin{array}{l}\text { Total } \\
\text { sugar } \\
\text { content }\end{array}$ & $\begin{array}{l}\alpha \text {-Glucosidase } \\
\text { inhibition (\%) }\end{array}$ \\
\hline \multirow[t]{2}{*}{ P. citrinopileatus } & Substrate I & $67 \pm 2^{a}$ & \multicolumn{2}{|c|}{$117 \pm 5^{a}$} & \multicolumn{2}{|c|}{$20 \pm 3^{a}$} & $58 \pm 5^{a}$ & $89 \pm 3^{a}$ & $29 \pm 2^{\mathrm{a}}$ & $25.4 \pm 0.4^{n}$ & $299 \pm 2^{b}$ & - \\
\hline & Substrate II & $62 \pm 3^{a}$ & & & $15 \pm 3$ & & $62 \pm 4^{\text {at }}$ & $75 \pm 4^{b}$ & $7 \pm 1^{e}$ & $30 \pm 4^{\mathrm{be}}$ & $365 \pm 9^{a}$ & $1.2 \pm 0.2^{*}$ \\
\hline \multirow{2}{*}{$\begin{array}{l}\text { P. salmoneo- } \\
\text { stramineus }\end{array}$} & Substrate I & $64 \pm 4^{a}$ & 79 & $\pm 1^{\mathrm{b}}$ & $3.8 \pm 0$ & $0.7^{\mathrm{e}}$ & $62 \pm 4^{\text {ath }}$ & $57 \pm 2^{e} \quad 1$ & $16.2 \pm 0.5^{b}$ & $31.8 \pm 0.3^{c}$ & $233 \pm 12^{e}$ & \\
\hline & Substrate II & $60 \pm 3^{a}$ & 87 & $\pm 5^{b}$ & $11.1 \pm 0$ & $0.8^{\mathrm{b}}$ & $59 \pm 3^{n}$ & $51 \pm 3^{b}$ & $20 \pm 6^{\text {thb }}$ & $26 \pm 1^{\text {ab }}$ & $191 \pm 9^{d}$ & $7.1 \pm 0.2^{b}$ \\
\hline
\end{tabular}

Negative impact of SCG was however observed for production of P. salmoneo-stramineus. Statistically significant lower production was obtained using substrate II representing $85.2 \%$ of losses (Table 1) with mushrooms being smaller and without characteristic oyster cap (data not shown) presenting also differences in terms of proximate composition: lower total protein, higher total sugar and $0.06 \mathrm{~g} / 100$ gdry mushroom of caffeine. Variable values of biological efficiency [(mushroom wet weight/substrate dry weight) $\times 100 \%]$ and straindependent have been reported for P. djamor mushrooms grown in coffee pulp (Salmones \& Mata, 2002; Salmones et al., 2005).

Mushrooms, independent of the species grown in substrate II, had similar caffeine contents to those observed in the dry substrate (0.07$0.11 \mathrm{~g} / 100$ gdry substrate) before inoculation suggesting that fungal mycelium was not able to degrade caffeine during growth but alternatively accumulated it thus justifying, at least in part, its content a posteriori in the fruiting bodies. This is in agreement with Salmones et al. (2005) observations who reported decreased content in the coffee pulp substrate precisely during fruiting stages and $0.17 \%-0.22 \%$ of caffeine in the respective mushrooms. 
Different extraction methods and biological potential of the extracts

Extraction yields obtained by different extraction modes on both species grown in the different substrate are displayed in Table 1. Higher yields were obtained by aqueous and enzymatic extraction than by ethanolic extraction. Lower yields values were however reported by Lee et al. (2007) for hot and cold water extraction (41-52 g/100 g) or ethanolic extraction (20 g/100 g) on P. citrinopileatus mushrooms.

No significant effects between species and substrates were observed $(P>0.05)$ for aqueous extracts. Some variations were however observed between enzymatic extracts and ethanolic extracts (Table 1). For these two types of extracts, statistically significant higher values $(P<0.05)$ were recorded for $P$. citrinopileatus grown in substrate II incorporating SCG, whereas for $P$. salmoneo-stramineus, higher values were observed for extracts resulting from fruit bodies grown in substrate I, without SCG. These values evidence some probable synergistic effects between the impact of SCG on structural and compositional characteristics of mycelium cells in the fruiting bodies decreasing the extraction yield for P. salmoneo-stramineus but not for P. citrinopileatus. Due to sample constraints, only total sugar content was determined in the different extracts (Table 1). As expected, higher content of total sugar was observed in the ethanolic extracts with highest value of all recorded in the extract from P. citrinopileatus grown in substrate II. Lower values of total sugar content were observed generally in the extracts obtained from P. salmoneo-stramineus independently of organic substrate used for mushroom cultivation but dependent of extraction mode: EtOH Ext>HWE>EAE_Alc (Table 1).

\section{Antidiabetic activity}

In general, $\alpha$-glucosidase inhibitory activity was lower in all extracts (Table 1) in comparison with acarbose (a drug able to reduce serum glucose levels and used as positive control) which was approximately of $89 \%$. Variable antidiabetic potential was observed in the aqueous and enzymatic extracts regardless the species or organic substrates. The extracts that showed less potential were the ethanolic extracts evidencing that a high content of polysaccharides seems not be the main factor in the inhibitory activity of the $\alpha$-glucosidase but in turn, SCG in the organic substrate appears as a positive factor in particular for extracts of P. salmoneo-stramineus. In general, enzymatic extracts, and in particular the extract from P. citrinopileatus grown in substrate I, were shown to have the highest antidiabetic potential (Table 1). In terms of species, higher values were also obtained with P. citrinopileatus, especially in the aqueous and enzymatic extracts obtained from mushrooms grown in substrate I. The general lower values of antidiabetic potential compared to acarbose contradict those published by Khan \& Tania (2012) in vivo trials with aqueous extracts of Pleurotus spp. mushrooms which were promising by promoting the reduction in blood glucose levels $(16 \%-23 \%)$ in rats.

\section{Antioxidant activity}

The antioxidant potential of the different extracts was evaluated by different methods (Fig. 1). Some correlation is observed between the higher values of TPC observed and higher yield values (Table 1); higher content of TPC was recorded in aqueous and enzymatic extracts in comparison with ethanolic extracts (Fig. 1a) which are particularly rich in total sugars (Table 1), suggesting that HWE and EAE_Alc are probably more favourable to extract phenolic compounds or other compounds that could have antioxidant activity. Edible mushrooms contain many antioxidant compounds such as carotenoids, flavonoids, phenolic compounds, polysaccharides and antioxidant enzymes (Vaz et al., 2010). Good antioxidant capacities have been reported for extracts of mushrooms including those of $P$. citrinopileatus which have been attributed to the presence of ascorbic acid, $\alpha$ - and $y$-tocopherols and total phenols (Lee et al., 2007). On the other hand, and independently of the extraction mode, the content in TPC changed according to mushroom species as well as organic substrate without a generalised trend. For example, in aqueous extracts, higher values were recorded in extracts from $P$. citrinopileatus grown on substrate I (11.9 $\pm 0.6 \mathrm{mg} \mathrm{GAE/glyoph} \mathrm{extract)} \mathrm{and} \mathrm{from} \mathrm{P.} \mathrm{salmoneo-stramineus} \mathrm{grown} \mathrm{in} \mathrm{substrate} \mathrm{II} \mathrm{(11.2} \pm 0.6 \mathrm{mg} \mathrm{GAE} / / \mathrm{glyoph}$ extract), respectively. These values are included in the range values of those published by Mishra et al. (2013) which varied between 3.94 and $21.67 \mathrm{mg}$ tannic acid equivalents per $\mathrm{g}$ of mycelium for several species of Pleurotus including P. djamor and P. citrinopileatus. In turn, by EAE with alcalase, the highest value was recorded in extracts from P. salmoneo-stramineus grown in substrate I (11.8 $\pm 0.8 \mathrm{mg}$ GAE/glyoph extract). In ethanolic extracts, slightly higher values were recorded for both species grown in substrate II (6.8-7.0 mg GAE/glyoph extract). Flavonoids, chlorogenic acid and protocatechuic acid were extracted from SCG by Mussato et al. (2011b) where extraction using $60 \%$ methanol in a solvent/solid ratio of $40 \mathrm{~mL} \mathrm{g-1} \mathrm{SCG} \mathrm{during} 90$ min was able to produce extracts with high content of phenolic compounds and high antioxidant activity. Chlorogenic acid has been reported as one of the most abundant phenolic 
compounds in SGC (Lee et al., 2007). According to Ramalakshmi et al. (2009), the presence of phenolic compounds including chlorogenic acid in appreciable amounts along with brown pigments in SCG extracts makes this coffee by-product a good source of antioxidants which could also possibly have a role in antitumour activity.
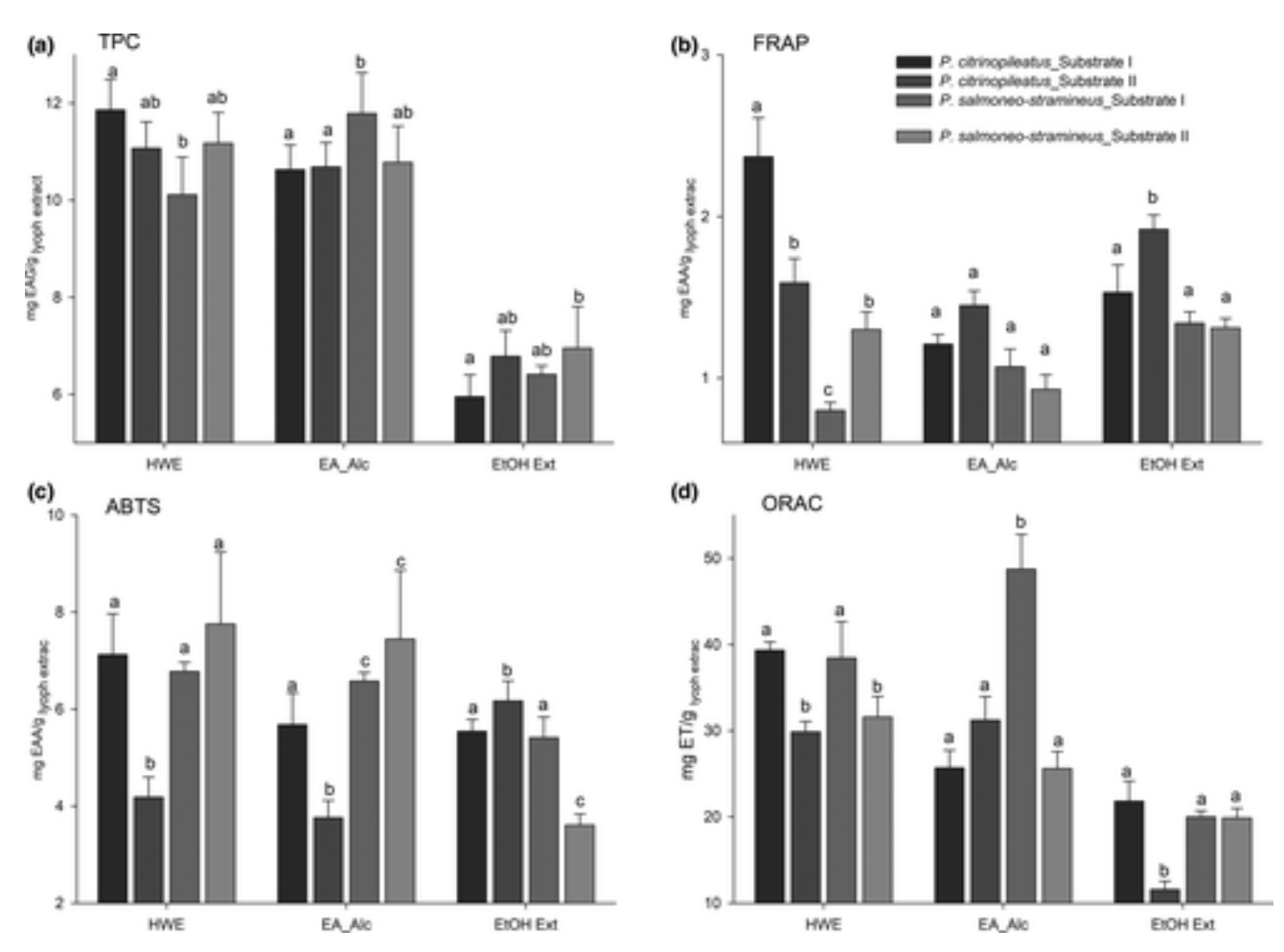

fig. 1 (a) Total phenolic content (TPC), (b) ferric reduction activity power (FRAP), (c) scavenging of radical ABTS $\bullet+$ (ABTS) and (d) oxygen radical absorption capacity (ORAC) of the extracts of Pleurotus citrinopileatus grown in substrate I (image) or substrate II (image) and of Pleurotus salmoneo-stramineus grown in substrate I (image) or substrate II (image), respectively. For each type of extraction, different lowercase letters indicate significant differences $(P<0.05)$ between extracts obtained from both species grown in the different substrates.

In terms of antioxidant activity observed in the different extracts (Fig. 1a-d), no general tendency was observed considering extraction mode, mushroom species or organic substrate and was not in agreement with TPC contents. The aqueous extracts of P. citrinopileatus grown in substrate I stood out in relation to the others presenting the highest values of TPC (11.9 $\pm 0.6 \mathrm{mg}$ EAG/glyoph extract), and of $\operatorname{FRAP}(2.4 \pm 0.2 \mathrm{mg}$ EAA/glyoph extract); for scavenging activity of radical ABTS $\bullet+(7.1 \pm 0.8 \mathrm{mg}$ EAA/glyoph extract) and oxygen radical

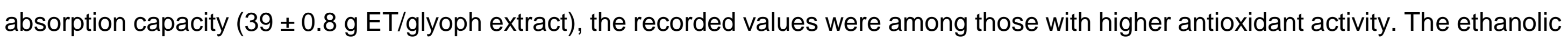
extracts, independently of the species and organic substrate, only present some antioxidant potential regarding FRAP (Fig. 1b). This tendency contrasts with main observation reported by Lee et al. (2007) where ethanolic extracts had consistently higher antioxidant activities than water extracts. In terms of enzymatic extracts resultant from Alcalase, some potential against radicals ABTS •+ and oxygen was observed for those resultant from P. salmoneo-stramineus grown on substrate I or II (Fig. 1c-d).

To evaluate the relationship between TPC and antioxidant activity determined by each different method, the respective correlation coefficients were determined. A correlation coefficient of 0.728 was obtained between TPC and ORAC, which suggests that the phenolic compounds present in the extracts appear to have a good absorption capacity for oxygenated radicals, in a positive relation to the species, organic substrate and extraction mode.

\section{Antihypertensive activity}

Antihypertensive potential of the extracts, determined as IC50, revealed that ethanolic extracts of both species were not able to exert any activity against ACE. In fact, a relevant antihypertensive activity was only observed with aqueous and enzymatic extracts from $P$. citrinopileatus grown in both organic substrates. These oscillated between good inhibition activity $(50<\mathrm{IC} 50<150)$ observed with aqueous extract of $P$. citrinopileatus grown in substrate I $(I C 50=123 \mu \mathrm{g} \mathrm{mL}-1)$ and intermediate inhibition activity $(150<\mid C 50<400)$ observed in aqueous extract of $P$. citrinopileatus grown in substrate II (IC50 $=276 \mu \mathrm{g} \mathrm{mL}-1)$ as well in enzymatic extracts of $P$. citrinopileatus grown in substrate I $(\mathrm{IC50}=178 \mu \mathrm{g} \mathrm{mL}-1)$ and II $(\mathrm{IC50}=243 \mu \mathrm{g} \mathrm{mL}-1)$, respectively. According to these results, apparently neither Alcalase activity nor organic substrate containing SCG were factors of added value in terms of antihypertensive activity. Surprisingly, no antihypertensive activity was recorded with any of the extracts from P. salmoneo-stramineus despite the higher content of protein in their fruiting bodies, even in those extracts resulting from Alcalase extraction. Abdullah et al. (2012) evaluated the ACE inhibitory activity of some edible culinary-medicinal mushrooms extracts, including some species of Pleurotus, extracted by boiling in water for 30 min reporting values of IC50 between 50 and $67 \mu \mathrm{g} \mathrm{mL}-1$. 
The selection of tested extracts and probiotic strains was based on absorbance growth curves through $24 \mathrm{~h}$ of incubation at $37{ }^{\circ} \mathrm{C}$ of four probiotic bacteria (L. casei L26, L. acidophilus Ki, B. animalis Bo e and B. lactis Bb12) in microplate using MRS broth supplemented with controls (2\%) or with all of the different extracts (2\%) as carbon sources (data not shown). From this study, two probiotic bacteria were selected as well as two types of extracts for confirmation of prebiotic activity over $48 \mathrm{~h}$ of incubation at $37^{\circ} \mathrm{C}$ : (i) the aqueous and ethanolic extracts were selected because of the higher exponential growth; (ii) B. animalis Bo was chosen because it was the most promising in comparison with $\mathrm{B}$. lactis $\mathrm{Bb12}$, and (iii) $\mathrm{L}$. acidophilus Ki was selected mainly because this is a more fastidious and challenging probiotic bacteria in comparison with L. casei L26.

Probiotic viable cells and $\mathrm{pH}$ variation (Fig. 2) as well as sugars consumption and organic acids production (Table 2) were determined over $48 \mathrm{~h}$ of incubation at $37^{\circ} \mathrm{C}$. The higher prebiotic potential was observed using ethanolic extracts regardless the mushroom species or organic substrate, which is certainly related with its higher total sugar contents being 2.2-3.3 higher than HWE extracts (Table 1). The evolution of the number of viable cells of B. animalis Bo in MRS supplemented with the ethanolic (Fig. 2a) or aqueous extracts (Fig. $2 b)$ of both species of mushrooms grown on the two organic substrates was very similar to those observed in MRS supplemented with the positive controls glucose or FOS controls during the exponential phase ( $0-8 \mathrm{~h}$ ), and beginning of the stationary phase (8-12 $\mathrm{h}$ ). After $10 \mathrm{~h}$ of incubation, slightly higher values of viable cells of B. animalis Bo were recorded in MRS supplemented with the ethanolic extracts, particularly after 24 and $48 \mathrm{~h}$ with extracts of $\mathrm{P}$. salmoneo-stramineus, compared to MRS supplemented positive controls (Fig. 2a). It was also noted that the numbers of viable cells of $B$. animalis Bo in MRS supplemented with the aqueous extracts (Fig. 2b), regardless of the mushroom species and the organic substrate, remained more stable after 24 and $48 \mathrm{~h}$ of incubation, than with the ethanolic extracts for which it was registered a decline after $24 \mathrm{~h}$ (Fig. 2a,b). Thus, the ethanolic and aqueous extracts of both species of mushrooms shown to be a very efficient alternative source for growth of $B$. animalis Bo demonstrating a good prebiotic potential. Specific growth rates of B. animalis Bo obtained in MRS with ethanolic extracts are slightly higher than those obtained in MRS with FOS, in particular with extracts resultant from P. citrinopileatus grown in both of the organic substrates (Fig. 2a); statistical significant lower specific rates were obtained in MRS with or without glucose. With aqueous extracts, a similar scenario was observed but specific growth rates in MRS with these extracts were slightly lower than those obtained in MRS with FOS.
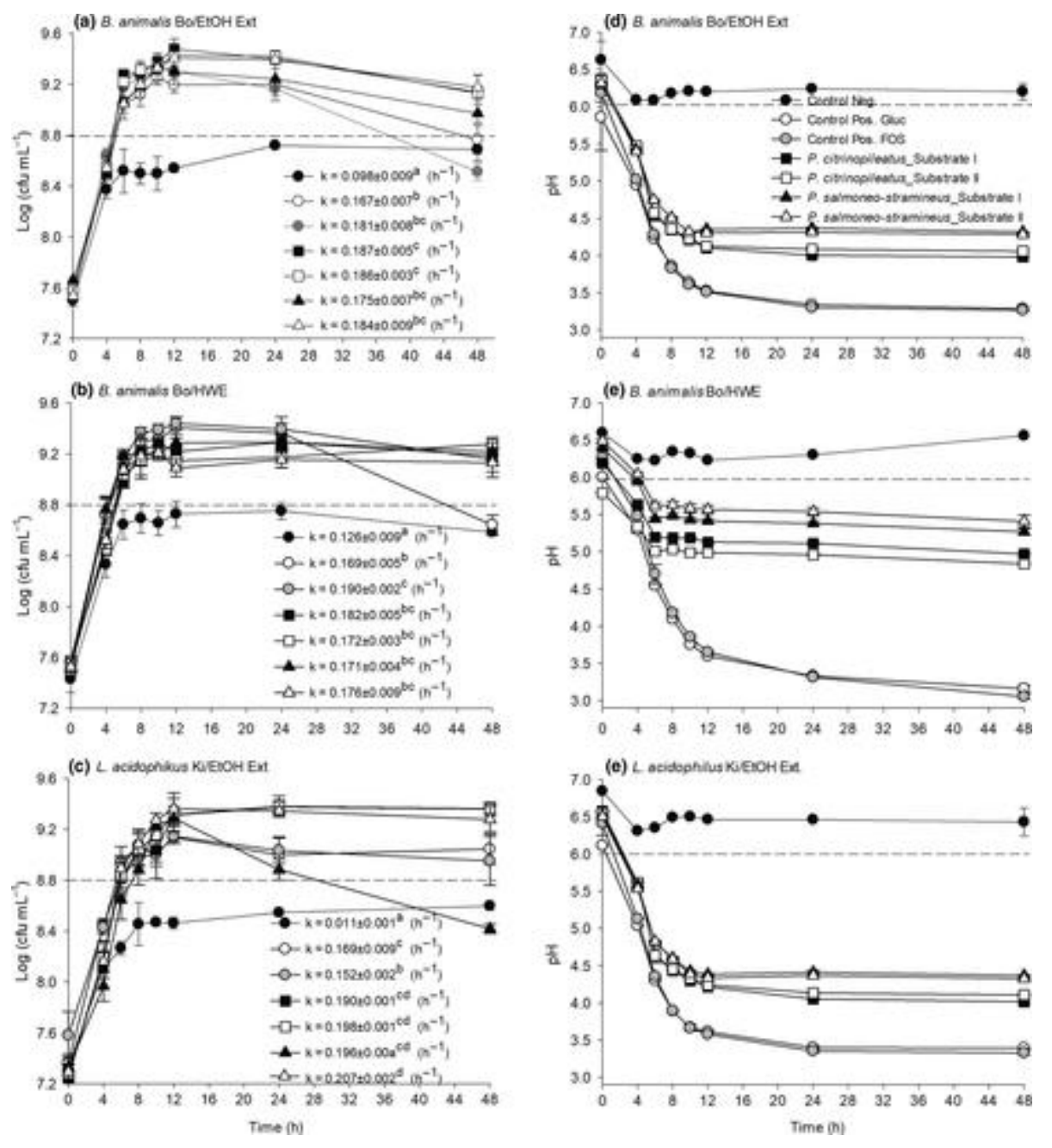

fig. 2 Number of viable cells ( $a, b$ and $c$ ) and respective variation in $\mathrm{pH}\left(\mathrm{d}\right.$, e and f) of Bifidobacterium animalis Bo or Lactobacillus acidophilus $\mathrm{Ki}$ throughout $48 \mathrm{~h}$ of incubation at $37{ }^{\circ} \mathrm{C}$ in

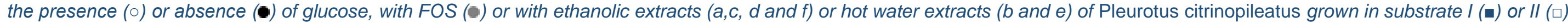
and of Pleurotus salmoneo-stramineus grown in substrate I $(\mathbf{\Delta})$ or II $(\Delta)$, respectively. For each growth curve, specific rate growth $\left(h^{-1}\right)$ is presented. 
Table 2 Content of glucose and of FOS in the respective positive controk (MRS with glucose or MRS with FOS) and of organic acids over 48 h of incubation at $37{ }^{\circ} \mathrm{C}$ in controls or in MRS added with different extracts and inoculated with Bifidabacterium animalis Bo or Lactobacillus adidophilus $\mathrm{Ki}$, respectively

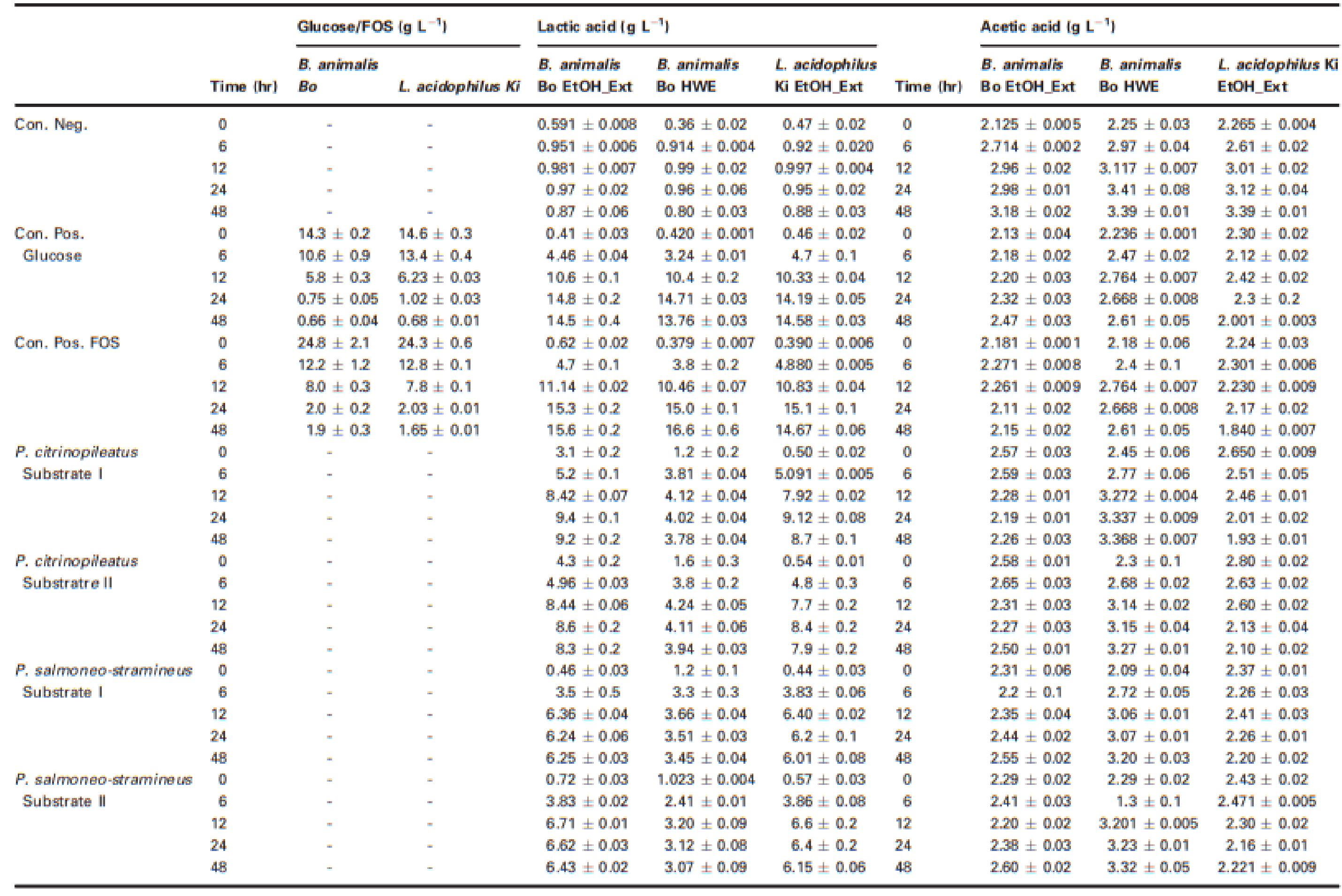

Regarding the variation in $\mathrm{pH}$ over $48 \mathrm{~h}$ of incubation, in general, a greater effect of the type of carbon source was observed. The decrease in $\mathrm{pH}$ values was much steeper in MRS supplemented with glucose and FOS shortly after $4 \mathrm{~h}$ (Fig. $2 \mathrm{~d}-\mathrm{f}$ ). Intermediate reduction was observed in MRS supplemented with extracts of $\mathrm{P}$. citrinopileatus while the lowest $\mathrm{pH}$ reduction occurred in MRS supplemented with extracts of $\mathrm{P}$. salmoneo-stramineus. This trend was more pronounced in MRS with ethanolic extracts where lower $\mathrm{pH}$ values were verified over time (Fig. 2c and f) compared to those obtained in MRS with aqueous extracts (Fig. 2e). This fact is certainly related to the higher availability of fermentable sugars present in the ethanolic extracts. There was no particular effect by SCG in the organic substrate on $\mathrm{pH}$ profile over $48 \mathrm{~h}$ of incubation.

Concerning the number of viable cells of $\mathrm{L}$. acidophilus $\mathrm{Ki}$ in MRS supplemented with the ethanolic extracts and their respective $\mathrm{pH}$ variation over $48 \mathrm{~h}$ of incubation (Fig. $2 \mathrm{c}-\mathrm{f}$ ), a similar scenario is observed in general to that obtained with B. animalis Bo. However, some aspects can be highlighted: (i) after $12 \mathrm{~h}$, a more marked decrease in the number of viable cells of L. acidophilus Ki in MRS supplemented with ethanolic extract of P. salmoneo-stramineus produced with substrate I (without SCG) was observed (Fig. 2c); (ii) a greater difference was observed between the number of viable cells of L. acidophilus Ki in MRS supplemented with the other three ethanolic extracts in comparison with MRS supplemented with glucose or with FOS, particularly after 24 and $48 \mathrm{~h}$; (iii) the pH variation in MRS with each of the four ethanolic extracts was similar to that obtained with $\mathrm{B}$. animalis Bo. The pH variation was not affected by the decrease in viable cells of L. acidophilus Ki in MRS supplemented with ethanolic extract of $\mathrm{P}$. salmoneo-stramineus produced on substrate I (Fig. 2c-f). Specific growth rates of L. acidophilus Ki obtained in MRS with ethanolic extracts were statistically significant higher than those obtained in MRS with FOS, in particular with extracts resultant from P. salmoneo-stramineus grown in substrate II incorporating SCG (Fig. 2c); statistically significant lower specific rates were obtained in MRS with glucose.

In general, all the selected ethanolic and aqueous extracts were evidenced as good alternative carbon sources showing good prebiotic potential in comparison with the recognised prebiotic FOS. Mushrooms have been referred as potential candidates for alternative prebiotic sources because they contain polysaccharides such as chitin, hemicellulose, $\beta$ - and $\alpha$-glucans, mannans, xylans and galactans (Aida et al., 2009); Pleurotus is an excellent source of crude fibre $( \pm 10 \%)$ and $\beta$-glucans (25\%) (Carrasco-González et al., 2017$)$. 
According to Synytsya et al. (2008), the variable use of different extracts from P. ostreatus and P. eryngii by probiotics evidences different chemical structure of the polysaccharides behind the prebiotic potential; according to the authors, at least two types of glucans and proteoglucan complexes from Pleurotus could be used for synbiotic effect. In another example, Rodrigues et al. (2016) reported that digested Pholiota nameko enzymatic extract obtained with Flavourzyme selectively increases bifidobacteria, hindering growth of Clostridium histolyticum as well as member of the Clostridium coccoides/Eubacterium rectale group, which associated to consistent increase in short-chain fatty acids and lactic acid production suggests its potential prebiotic character. These results confirmed the potential prebiotic activity observed for this extract on L. acidophilus La5 and B. animalis BB12 (Rodrigues et al., 2017).

Consumption of glucose and FOS was similar among both probiotic strains: $57 \%-59 \%$ consumption of glucose after $12 \mathrm{~h}$, reaching values of $95 \%$ after $48 \mathrm{~h}$, whereas consumption of FOS was of $68 \%$ after $12 \mathrm{~h}$ reaching values of $92 \%-93 \%$ after $48 \mathrm{~h}$ (Table 2 ). As expected, the consumption of glucose and FOS during fermentation was accompanied by the production of organic acids, in particular of high contents of lactic acid by both probiotic bacteria (Table 2) which is also in agreement with higher acidification levels recorded by $\mathrm{pH}$ values for both the positive controls (Fig. 2d-f). Regarding lactic acid production in MRS supplemented with ethanolic or aqueous extracts, similar profile to those obtained with positive controls was observed although lower contents were recorded between 12 and $48 \mathrm{~h}$ (Table 2). However, the progressive production of lactic acid was totally proportional to the $\mathrm{pH}$ variation observed; for example, lower contents were obtained with aqueous extracts in particular with those resultants from $\mathrm{P}$. salmoneo-stramineus without higher differences due to the organic substrates. The concomitant expected production of acetic acid by B. animalis Bo, given its heterofermentative nature, was not verified independently of the growth conditions (Table 2).

\section{Conclusions}

Both Pleurotus species are able to be cultivated in different organic substrates involving SCG, a major by-product resultant from coffee industry. Whereas incorporation of SCG in the organic substrate enabled maximum production yield of P. citrinopileatus [25.1\% (w/w)], it had some negative effect on P. salmoneo-stramineus growth and yield. Taking into consideration the achieved results in this study, it becomes difficult to pinpoint the most promising combination in terms of mushrooms species and organic substrate regarding (i) yield growth, (ii) mushroom composition and (iii) highest biological potential of the respective extracts. As SCG is a food by-product that could be better reutilised in different applications, this study has revealed its successful use in the cultivation of $P$. citrinopileatus which when combined with aqueous extraction results in extracts with potential biological properties especially in terms of antioxidant activity by its content of in TPC (11.1 $\pm 0.6 \mathrm{mg} \mathrm{GAE/glyoph} \mathrm{extract)} \mathrm{or} \mathrm{prebiotic} \mathrm{activity} \mathrm{in} \mathrm{comparison} \mathrm{with} \mathrm{FOS.} \mathrm{This} \mathrm{very} \mathrm{much} \mathrm{opens} \mathrm{doors} \mathrm{to} \mathrm{a}$ more efficient use of SCG where sustainability and cost-effectiveness are needed within a circular economy perspective (zero waste).

\section{Acknowledgments}

The authors are grateful to ORAFTI, CSK and DSM for providing the FOS and the probiotic strains, respectively. This work was supported by national funds through FCT/MEC (PIDDAC), project reference IF/00588/2015 with scientific collaboration of CBQF under the FCT project UID/Multi/50016/2013.

\section{References}

Abdullah, N., Ismail, S.M., Aminudin, N., Shuib, A.S. \& Lau, B.F. (2012). Evaluation of selected culinary-medicinal mushrooms for antioxidant and ACE inhibitory activities. Evidence-Based Complementary and Alternative Medicine, 2012, 12. Article ID 464238. https://doi.org/10.1155/2012/464238

Aida, F.M.N., Shuhaimi, M., Yazid, M. \& Maaruf, G. (2009). Mushroom as a potential source of prebiotics: a review. Trends Food Science \& Technology, 20, 567-575.

AOAC, (1990). Official methods of analysis. (15th ed). Arlington, VA: Association of Official Analytical Chemists. 
Carrasco-González, J.A., Serna-Saldívar, O. \& Gutiérrez-Uribe, J.A. (2017). Nutritional composition and nutraceutical properties of the Pleurotus fruiting bodies: potential use as food ingredient. Journal Food Composition and Analysis, 58, 69-81.

Dubois, M., Gilles, K.A., Hamilton, J.K., Rebers, R.A. \& Smith, F. (1956). Colorimetric method for determination of sugars and related substances. Analytical Chemistry, 28, 350-356.

Echeverria, M.C. \& Nuti, M. (2017). Valorization of residues of coffee agro-industry: perspectives and limitations. Open Waste Management Journal, 10, 13- 22.

Esquivel, P. \& Jiménez, V.M. (2012). Functional properties of coffee and coffee by-products. Food Research International, 46, 488495.

Herrero, M., Cifuentes, A. \& Ibañez, E. (2006). Sub- and supercritical fluid extraction of functional ingredients from different natural sources: plants, food-by-products, algae and microalgae. Food Chemistry, 98, 136- 148.

ISO 20481:2008. (2008). Coffee and coffee products. Determination of the caffeine content using high performance liquid chromatography (HPLC). Reference method.

Khan, M.A. \& Tania, M. (2012). Nutritional and medicinal importance of Pleurotus mushrooms: an Overview. Food Reviews International, $28,313-329$.

Kulshreshtha, S., Mathur, N., Bhatnagar, P. \& Kulshreshtha, S. (2013). Cultivation of Pleurotus citrinopileatus on handmade paper and cardboard industrial wastes. Industrial Crops Products, 41, 340-346.

Lee, Y., Huang, G., Liang, Z. \& Mau, J. (2007). Antioxidant properties of three extracts from Pleurotus citrinopileatus. LWT-Food Science \& Technology, 40, 823-833.

Martínez-Carrera, D., Guzmán, G. \& Soto, C. (1985). The effect of fermentation of coffee pulp in the cultivation of Pleurotus ostreatus in Mexico. Mushroom Newsletter Tropical, 6, 21- 28.

Mata, G., Hernández, D.M.M. \& Andreu, L.G.I. (2005). Changes in lignocellulolytic enzyme activities in six Pleurotus spp. strains cultivated on coffee pulp in confrontation with Trichoderma spp. World Journal Microbiology \& Biotechnology, 21, $143-150$.

Mendes, M., Carvalho, A.P., Magalhães, J.M.C.S. et al. (2016). Response surface evaluation of microwave-assisted extraction conditions for Lycium barbarum bioactive compounds. Innovation Food Science \& Emerging Technologies, 33, 319- 326.

Mishra, K.K., Pal, R.S., ArunKumar, R., Chandrashekara, C., Jain, S.K. \& Bhatt, J.C. (2013). Antioxidant properties of different edible mushroom species and increased bioconversion efficiency of Pleurotus eryngii using locally available casing materials. Food Chemistry, 138, 1557-1563.

Moon, B. \& Lo, Y.M. (2013). Conventional and novel applications of edible mushrooms in today's food industry. Journal Food Processing \& Preservation, 38, 2146- 2153. 
Mussato, S.I., Machado, E.M.S., Martins, S. \& Teixeira, J.A. (2011a). Production, composition and application of coffee and its industrial residues. Food Bioprocessing \& Technology, 4, 661- 672.

Mussato, S.I., Ballesteros, L.F., Martins, S. \& Teixeira, J.A. (2011b). Extraction of antioxidant phenolic compounds from spent coffee grounds. Separation \& Purification Technology, 83, 173- 179.

Paz, M., Gúllon, P.H., Barroso, M.F. et al. (2015). Brazilian fruit pulps as functional foods and additives: evaluation of bioactive compounds. Food Chemistry, 172, 462-468.

Petre, M., Florin, P. \& Teodorescu, R.I. (2016). Controlled cultivation of mushrooms on winery and vineyard wastes. In: Mushroom Biotechnology: developments and Applications. (edited by Marian Petre) Pp. 31- 48 London: Elsevier.

Philippoussis, A.N. (2009). Production of mushrooms using agro-industrial residues as substrates. In: Biotechnology for Agro-Industrial Residues Utilisation. (edited by P. Singh nee' Nigam \& A. Pandey) Pp. 163- 196 New York, NY: Springer.

Ramalakshmi, K., Rao, L.J.M., Takano-Ishikawa, Y. \& Goto, M. (2009). Bioactivities of low-grade green coffee and spent coffee in different in vitro model systems. Food Chemistry, 115, 79- 85.

Rodrigues, D., Rocha-Santos, T.A.P., Pereira, C.I., Gomes, A.M., Malcata, F.X. \& Freitas, A.C. (2011). The potential effect of FOS and inulin upon probiotic bacterium performance in curdled milk matrices. LWT-Food Science \& Technology, 44, $100-108$.

Rodrigues, D., Sousa, S., Silva, A.G. et al. (2015). Impact of enzyme- and ultrasound-assisted extraction methods on biological properties of red, brown, and green Seaweeds from the Central West Coast of Portugal. Journal Agriculture \& Food Chemistry, 63, $3177-3188$

Rodrigues, D., Walton, G., Sousa, S. et al. (2016). In vitro fermentation and prebiotic potential of selected extracts from seaweeds and mushrooms. LWT-Food Science \& Technology, 73, 131- 139.

Rodrigues, D., Freitas, A.C., Sousa, S. et al. (2017). Chemical and structural characterization of Pholiota nameko extracts with biological properties. Food Chemistry, 216, 176- 185.

Sabaratnam, V., Kah-Hui, W., Naidu, M. \& David, P.R. (2011). Neuronal health - can culinary and medicinal mushrooms help? Journal of Traditional Complementary Medicine, 3, 62- 68.

Salmones, D. \& Mata, G. (2002). Detection of extracellular enzymes produced by Pleurotus spp. grown on coffee pulp. In Proceedings of the Fourth International Conference on Mushroom Biology and Mushroom Products. Pp. 213-219. Morelos, Mexico.

Salmones, D., Mata, G. \& Waliszewski, K.N. (2005). Comparative culturing of Pleurotus spp. on coffee pulp and wheat straw: biomass production and substrate biodegradation. Bioresearch Technology, 96, 537-544. 
Synytsya, A., Mickova, K., Synytsya, A., Jablonsky, I., Spevacek, J. \& Erban, V. (2008). Glucans from fruit bodies of cultivated mushrooms Pleurotus ostreatus and Pleurotus eryngii: structure and potential prebiotic activity. Carbohydrate Polymers, 76, 548- 556.

Tavares, T., Contreras, M., Amorim, M. \& Pintado, M. (2011). Novel whey-derived peptides with inhibitory effect against angiotensinconverting enzyme: in vitro effect and stability to gastrointestinal enzymes. Peptides, 32, 1013-1019.

Thielke, C. (1989). Cultivation of edible fungi on coffee grounds. Mushroom Science, 12, 337-343.

US ISO 5983-1 (2009) Animal feeding stuffs. Determination of nitrogen content and calculation of crude protein content. Part 1: Kjeldahl method. Uganda National Bureau of Standards.

Vaz, J.A., Heleno, S.A., Martins, A., Almeida, G.M., Vasconcelos, M.H. \& Ferreira, I.C.F.R. (2010). Wild mushrooms Clitocybe alexandri and Lepista inversa: In vitro antioxidant activity and growth inhibition of human tumor cell lines. Food Chemistry \& Toxicology, 48, 28812884.

Velázquez-Cedeño, M.A., Mata, G. \& Savoie, J. (2002). Waste-reducing cultivation of Pleurotus ostreatus and Pleurotus pulmonarius on coffee pulp: changes in the production of some lignocellulolytic enzymes. World Journal Microbiology \& Biotechnology, $18,201-207$.

Wang, J., Zhang, Q., Zhang, Z., Song, H. \& Li, P. (2010). Potential antioxidant and anticoagulant capacity of low molecular weight fucoidan fractions extracted from Laminaria japonica. International Journal Biological Macromolecular, 46, 6- 12. 